\title{
Nutrition and sensory evaluation of germinated cereals and pseudocereals
}

\author{
Renáta Dlouhá ${ }^{1}$, Karin Petřeková ${ }^{*}$, Ivo Hartman ${ }^{2,1}$, Jaroslav Šimek ${ }^{3,1}$, Vítězslav Hertel ${ }^{3}$ \\ Department of Physiology and Pathophysiology, Faculty of \\ Medicine, University of Ostrava, Syllabova 19, \\ 3 SEMIX PLUSO, spol. s.r.o, Rybničky 338, 74781 Otice, Czech
Republic \\ 70300 Ostrava-Vitkovice, Czech Republic \\ 2 Research Institute of Brewing and Malting, Mostecká 971/7, \\ *corresponding author: karin.petrekova@osu.cz
} 61400 Brno, Czech Republic

\section{ABSTRACT}

Our study is focused on comparison of nutritional, functional and sensory properties of buckwheat (Fagopyrum sagitatum), naked gluten-free oats (Avena sativa), and quinoa - Chilean gooseberry (Chenopodium quinoa). The input material was raw seeds of the mentioned types of cereals and pseudo-cereals, which were subjected to a germination process under defined conditions and subsequently processed into a form of dried groats or flakes. Basic nutritional parameters were determined for samples of non-germinated seeds and final products, supplemented by determination of antioxidant activity. $\beta$-Glucans were evaluated in gluten-free naked oats. Their content in the final product decreased by $43.7 \%$, yet it reached favourable values of $2.2 \mathrm{~g}$ per $100 \mathrm{~g}$ of product. A significant increase in energy content by approximately $6.4-9.2 \%$ was found. This increase was influenced by an increase in the carbohydrate content of all final products. As with raw seeds, germinated seeds of the monitored cereals and pseudo-cereals treated by drying have a low content of fats, saturated fatty acids, sugars and they are a good source of protein and fibre. A significant increase in antioxidant activity was observed only in flakes of germinated gluten-free oats. The sensory evaluation of the final products was favourable. On drying, the germinated seeds of the examined samples acquired a brittle structure, which together with the taste was the best evaluated property of the final products. The products represent a new, nutritionally interesting alternative to regular nutrition and gluten-free diets.

Keywords: germination, quinoa, oats, buckwheat

\section{Introduction}

Cereals and pseudo-cereals are among the most important foods for most humans (Kocková, 2013). They are usually consumed in the form of bread, breakfast cereals or cereal bars. Wheat and rice are the world's most produced cereals. Less produced but no less important is barley. Most of the produced barley is used for brewing. In addition to the main cereals, there are other types of cereals and pseudo-cereals such as sorghum, millet, reedgrass, canary grass, oats, triticale, rye, buckwheat and quinoa (Schoenlechner, 2016). They are good sources of carbohydrates, especially starch and fibre, proteins, lipids and minerals. Proteins are characterized by a good quality of amino acids, with the exception of lysine in case of ce- reals. Lipids are represented by essential fatty acids. The most important vitamins are the B complex; the minerals are mainly calcium, potassium, magnesium, iron, zinc, copper, and phosphorus. Like legumes, cereals also contain antinutritional substances such as phytates, tannins and enzyme inhibitors (Kocková, 2013; Bulková, 2011).

Appropriate treatments such as germination, fermentation, but also soaking before heat treatment, can reduce the content and effect of antinutritional agents (Saratu and Matthew, 2011). An advantage of germination is an increase in protein or fibre contents and a reduction in fat. The increase in protein is attributed to protein synthesis in the germination process and the de- 
crease in fat to the metabolic activity of the seeds (Saratu and Matthew, 2011). By germinating the seeds, we can achieve significant biochemical and nutritional changes that can be beneficial to our health and overall nutritional status. Germination is a natural process in which a germ grows from the seed of a plant. Seeds before germination go through a period of rest, which is important in terms of overcoming unfavourable conditions. Under favourable conditions, a seed then germinates and develops into a plant (Rusydi and Azrina, 2012).

A study on the germination of quinoa and the effect of germination on the digestibility of seed proteins and trypsin inhibitory activity in germinated quinoa showed that biochemical processes during germination reduced trypsin activity, although protein digestibility did not change by germination (Amista and Tavano, 2013).

One of the studies was also carried out on the less common Coix lacryma-jobi and concerned changes in nutritional and physico-chemical properties that occur in the germination process. Among other things, this study found that gamma-aminobutyric acid (GABA), which is responsible for the regulation of muscle tone in the human body, increased 3-4 times during germination of the Coix lacryma-jobi (Xu et al., 2017).

Zhang et al. (2015) found improvements in overall nutritional value and antioxidant activity in buckwheat seeds germinated for more than 72 hours. In both cases, the improvement was significant. Germinated buckwheat could be used as a promising functional food to promote health; it represents an excellent natural source of flavonoids and phenolic compounds, especially rutin and C-glycosylflavones. Phenolic compounds such as rutin, vitexin, isovitexin, orientin, isoorientin, chlorogenic acid, trans-3-hydroxycinnamic acid and $p$-hydroxybenzoic acid increased significantly during the germination process, which may be due to the activation of phenylalanine ammonia lyase.

Buckwheat sprouts have a slightly crispy structure, a delicate taste and a pleasant smell. These parameters make the sprouts widely applicable for consumption or further processing (Sytar et al., 2016)

Many studies have shown (Tian et al., 2010) that oat has a high content of proteins and fatty acids and its nutritional properties, digestibility, and hence the quality of oat products can be improved by germination. In addition, oat is appreciated for its high content of $\beta$-glucans and phenolic compounds with high antioxidant activity. The results of the study showed, e.g., a slight increase in protein, a $30 \%$ increase in lysine and other free amino acids, a $60 \%$ to $20 \%$ reduction in starch and a decrease in phytic acid content from $0.35 \%$ to $0.11 \%$ in germinated oat.
The pseudo-cereals amaranth and quinoa were some of the main crops for Pre-Columbian cultures in Latin America, but their consumption and cultivation were suppressed after the Spanish conquest. In the mid-90s, their favourable nutritional properties, in particular their suitability for gluten-free food products, were again recognized and their production again increased. Immunological studies have shown that amaranth and quinoa do not contain gluten and can therefore be used in a gluten-free diet (Schoenlechner, 2016).

The pathogenesis of gluten-induced diseases is divided into autoimmune, allergic and non-autoimmune non-allergic (Hoffman and Sánchez, 2015). All diseases that fall into these groups require the patients to comply with the gluten-free diet as part of their treatment. Gluten-free diet is a necessity for many patients, but it also becomes fashionable as it is perceived by many as healthier. For this reason, the offer of gluten-free food assortment is constantly expanding.

Gluten-free diets are based on the exclusion of foods and products from wheat, barley, rye and oat. An exception may be oat, which according to Commission Implementing Regulation (EU) No 828/2014 may be described as 'gluten-free' provided that it meets the conditions of special production, preparation or processing by methods that prevent contamination with wheat, rye, barley or their hybrids; the gluten content of oat must not exceed $20 \mathrm{mg} / \mathrm{kg}$. It is necessary to monitor the labels on foods, which in addition to the nutritional composition of the product should also indicate the gluten content. Guaranteed gluten-free foods are marked with a crossed-out ear symbol. Adherence to strictly gluten-free diets places on consumers additional demands which are related to the technological processing of gluten-free meals, preservation of diet diversity and the intake of sufficient amounts of all nutrients.

Pseudo-cereals are of particular importance for the production of gluten-free foods. Special cereals may be used for all food processes, but they often require some modification of recipes or processing conditions, especially when used as a single cereal component. Particular attention should be paid to the sensory properties of food products developed from these unknown cereal varieties, since consumers only accept highly tasty products. The flavour of amaranth and quinoa is different from commonly consumed cereal products. It has been shown that cracking or roasting seeds before grinding improves their palatability. Much research has been done in this respect. It has already been shown that the replacement of $10-20 \%$ of wheat flour by these cereals or pseudo-cereals increases the nutritional properties of the final product and is sometimes even preferred in sen- 
sory development. By combining cereals and legumes in one product, the resulting amino acid array will be more balanced (Schoenlechner, 2016).

The aim of our research was to determine, analyse and compare the main nutritional parameters of input raw grains of selected cereals and pseudo-cereals with their germinated and subsequently dried versions. The aim of sensory evaluation of final products from cereals and pseudo-cereals was to obtain independent information about their sensory properties. Subsequently we endeavoured to determine whether the germination and subsequent drying of quinoa, buckwheat and naked oat seeds without gluten will significantly affect the nutritional value of these products, contribute to their better digestibility and whether these alternatives can be palatable to consumers.

\section{Materials and Methods}

\subsection{Samples}

The raw materials were samples of red quinoa seeds, buckwheat groats and gluten-free naked oats. Three input samples were taken from all cereal and pseudo-cereal commodities followed by 3 germinated samples after drying. The samples were labelled and sent for analysis.

\subsection{Soaking, germination and processing}

Germination and processing of cereals and pseudo-cereals took place in production hall 02 of the company SEMIX PLUSO.

The seeds were soaked for a specified period of time and then spread onto a germination floor where germination took place for a defined period of time (Table 1). The temperature during the germination was $16-18{ }^{\circ} \mathrm{C}$. After the germination, the grains were further processed, i.e. stabilized by steam and dried to the level of storable dry matter, i.e. to final products (Table 1). The final cereal products were germinated quinoa flakes (Figure 1), germinated buckwheat groats (Figure 2), germinated buckwheat flakes (Figure 3) and germinated gluten-free oat flakes (Figure 4).

\subsection{Microbiological analysis}

Determination of selected microbiological parameters (E. coli, enterobacteria, moulds) was performed by culture methods according to valid standards. Enterobacteriaceae - ISO 21528-2 (2017); E. coli - ISO 16649-2 (2001); Moulds - ISO 21527-2 (2008).

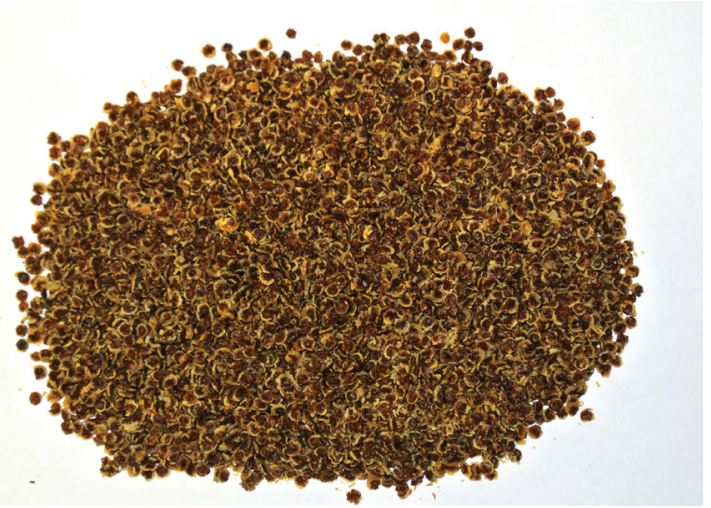

Figure 1 Germinated quinoa flakes

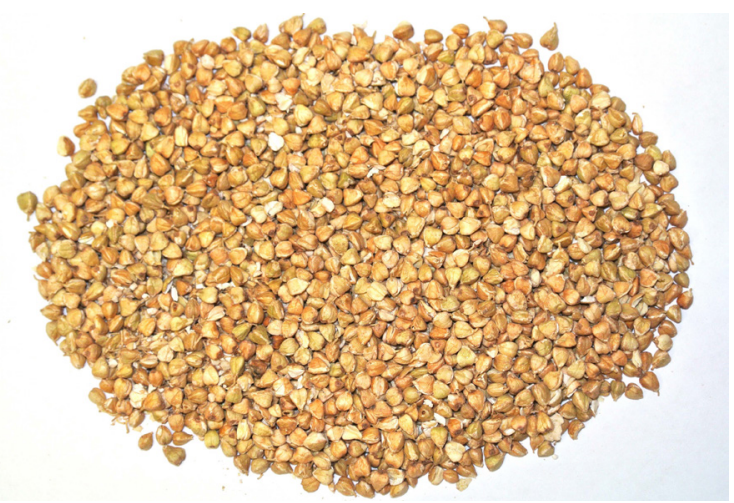

Figure 2 Germinated buckwheat groat

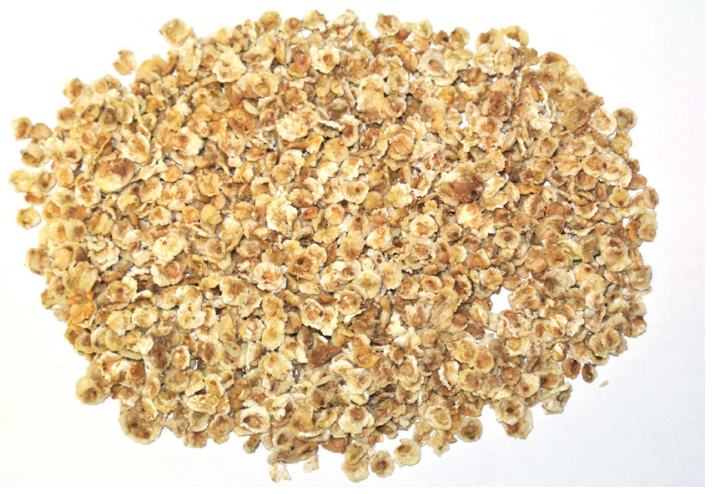

Figure 3 Germinated buckwheat flakes

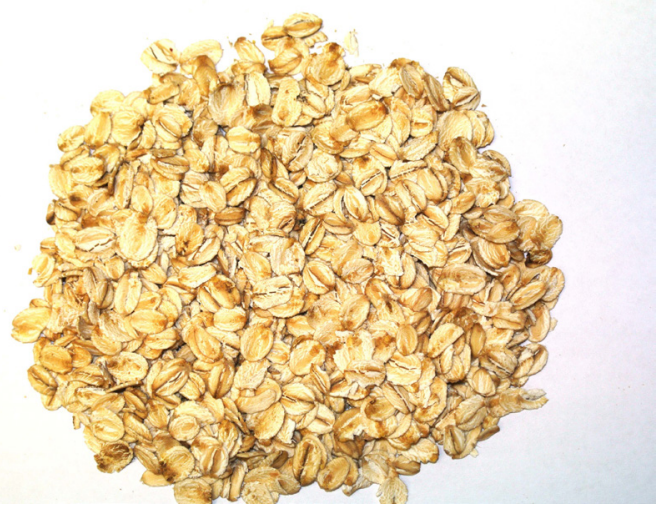

Figure 4 Germinated gluten-free oat flakes 
Table 1 Processing of raw materials into final products

\begin{tabular}{|c|c|c|c|c|}
\hline Feedstock & Soaking time (h) & Germination time (h) & Processing & Final product \\
\hline Quinoa & 3 & $17-19$ & $\begin{array}{l}\text { Steam stabilization, pressing, } \\
\text { drying }\end{array}$ & Germinated quinoa flakes \\
\hline \multirow[b]{2}{*}{ Buckwheat groats } & \multirow[b]{2}{*}{1} & $28-32$ & Drying & Germinated buckwheat groats \\
\hline & & $23-25$ & $\begin{array}{l}\text { Steam stabilization, pressing, } \\
\text { drying }\end{array}$ & Germinated buckwheat flakes \\
\hline $\begin{array}{l}\text { Gluten-Free Naked } \\
\text { Oats }\end{array}$ & 8 & $40-50$ & $\begin{array}{c}\text { Steam stabilization, pressing, } \\
\text { drying }\end{array}$ & $\begin{array}{l}\text { Germinated oat flakes } \\
\text { gluten-free }\end{array}$ \\
\hline
\end{tabular}

\subsection{Biochemical and nutritional parameters}

The nutritional values (energy, fat, saturated fatty acids, total carbohydrates, simple sugars, fiber, proteins) were analysed according to the requirements of Regulation (EU) No 1169/2011 of the European Parliament and European Council. The analyses were performed by EUROFINS CZ.

$\beta$-Glucans were determined using the fluorochrom Calcofluor, which forms complexes with high molecular weight $\beta$-glucans; this is reflected in an increase in the fluorescence intensity of this dye. Fluorescence was measured at an excitation wavelength of $365 \mathrm{~nm}$ and an emission wavelength of $425 \mathrm{~nm}$ with a fluorescence detector (EBC Analysis Committee, 2010).

The antioxidant activity was determined by the reaction of the test substance with the stable radical diphenylpicrylhydrazyl (DPPH), which reduces the radical to form diphenyl picrylhydrazine. The reaction was monitored spectrophotometrically at $517 \mathrm{~nm}$ (Benzie and Strain, 1999).

The antioxidant activity was measured by the FRAP assay based on the reduction of trivalent iron complex with 2,4,6-tri(2-pyridyl-1,3,5-triazine) ( $\mathrm{Fe}^{3+}$-TPTZ) by the antioxidants from the samples. The increase in absorbance at $593 \mathrm{~nm}$ corresponding to the $\mathrm{Fe}^{2+}-\mathrm{TPTZ}$ complex is a measure of antioxidant activity (Benzie and Strain, 1999).

\subsection{Sensory analysis}

The final germinated products were subjected to sensory evaluation by 12 trained tasters from the Research Institute of Brewing and Malting, Prague, and 22 untrained tasters/lay evaluators from RIBM Brno. Sensory evaluation parameters were colour, appearance, smell - pleasantness, intensity, crispness, structure, taste - pleasantness, intensity, salty taste, sweet taste, bitter taste - and overall impression.

The evaluators received samples in encoded containers and evaluated selected descriptors on a graphical scale. Water was administered as a taste neutralizer. The overall ranking was based on a rank test, where samples were compared on a scale of 1-7, 1 - best, 7 - worst. If the order was the same, the next place remained vacant. The evaluation of partial parameters that more specifically reflect the sensory character of the product was performed on a scale of $1-5$, where 1 is the best, 5 - the worst/serious defect.

\subsection{Statistical analysis}

The arithmetic mean and other characteristics (standard deviation, minimum and maximum values) were calculated for each series of measurements of the given commodity at the process input and output ( 3 samples). The variation coefficient $(\mathrm{v})$ was calculated for each series of measurements. Input/output comparison was expressed as \% change (arithmetic mean input/arithmetic mean output -1$) * 100 \%)$.

A paired t-test at a significance level of $5 \%$ was used for statistical evaluation of the change. MS Excel and Stata v. 14 were used to process the results.

\section{Study limits}

Each series contained only 3 measurements, so using a statistical test is problematic. Even in the case of a significant per cent change, it is also necessary to look at the variability of the measurement, i.e. variation coefficient. In case of a large variability, a statistically insignificant difference may occur for a large per cent difference. It is also important to consider statistical and material significance.

\section{Results and Discussion}

A statistically significant change was found in the energy value of all final products from the examined cereals and pseudo-cereals. There was an increase of $6.4 \%$ for the germinated quinoa flakes ( $p=0.0395), 7.2 \%$ for the germinated buckwheat groats $(p=0.0458), 7.7 \%$ for the germinated buckwheat flakes ( $p=0.0358$ ) 0.0002 ), and $9.2 \%$ for the germinated gluten-free oat flakes $(p=0.0015)$. An increase in the energy content 
is expected in case of an increase in the content of energy substrates for a given commodity, which was confirmed in our case, as the carbohydrate content of all final products increased.

The changes in the content of fats and saturated fatty acids were not statistically significant and their total content was low.

The content of saturated fatty acids in the germinated quinoa flakes reached $1.5 \%$ of the total energy value per $100 \mathrm{~g}$, while for the germinated buckwheat flakes it was $1.6 \%$ and for the germinated gluten-free oat flakes $2.5 \%$.

As already mentioned, an increase in total carbohydrates was found in all final samples, however, the sugar content did not change significantly for the germinated quinoa flakes and germinated gluten-free oat flakes and their content decreased significantly for the germinated buckwheat flakes ( $p=0.0339)$. Sugars include all monosaccharides and disaccharides present in the food, with the exception of polyalcohols, and their low content in final products corresponds to recommended nutritional trends aimed at reducing sugar by no more than $5-10 \%$ of daily energy intake (Regulation (EU) No 1169/2011).

An important part of nutrition is fibre. Fibre is defined as hydrocarbon polymers with three or more monomer units that occur naturally in food, are not digested and absorbed in the small intestine of the human body, but have a number of health benefits for humans (Regulation (EU) No 1169/2011). The daily recommended fibre intake according to the EFSA (European Food Safety Authority) for an adult is $25 \mathrm{~g}$. Cereals and pseudo-cereals are classified as excellent sources of fibre. Our results confirmed that germinated seeds of cereals and pseudo-cereals treated by drying can also be an important source of fibre. Its content was very favourable in the germinated quinoa flakes and germinated gluten-free oat flakes. The germinated quinoa flakes contained $12.7 \mathrm{~g}$ fibre and the germinated gluten-free oat flakes $7.2 \mathrm{~g}$ of fibre in $100 \mathrm{~g}$. These final products meet the conditions of those health claims, where a product that contains at least 6 grams of fibre per $100 \mathrm{~g}$ of this product can be described as high in fibre and a product that contains at least 3 grams of fibre per $100 \mathrm{~g}$ of this product can be described as a good source of fibre (Regulation (EC) No 1924/2006).

$\beta$-Glucans were measured in the germinated gluten-free oat flakes, resulting in a $43.7 \%$ reduction in their content $(p=0.0291)$. The content of $\beta$-glucans per $100 \mathrm{~g}$ of the non-germinated seeds of gluten-free oats was $4.0 \%$ and in the final product $2.2 \%$. Although a reduction in the $\beta$-glucan content of the germinated gluten-free oat flakes was observed in our study, their natural content per $100 \mathrm{~g}$ of product can still be considered significant. Due to the fact that the germinated flakes are gluten-free, the intake of $\beta$-glucans from the germinated gluten-free oat flakes can also be beneficial for people who follow a gluten-free diet.

The protein content decreased insignificantly, i.e. by $0.5 \%$ in the germinated quinoa flakes and by $1.5 \%$ in the germinated gluten-free oat flakes. It increased by $14.8 \%$ in the germinated buckwheat groats and by $7.6 \%$ in the germinated buckwheat flakes. Lemens et al. (2019) mention proteolysis after prolonged germination of cereal seeds and at higher temperatures. They indicate that germination leads to hydrolysis of proteins, but does not cause significant changes in the total protein content. The authors refer to studies that reported significant reductions in protein content. In contrast, other studies have reported a $5 \%$ to $10 \%$ increase in protein depending on the type of cereal. In their comparative study Botero et al. (2012) report a $26 \%$ increase in protein content, an increase in total fibre content by $118 \%$ and a $10 \%$ decrease in fat content after 168 hours of buckwheat germination. Jimenez et al. (2019) report, for example, for quinoa a statistically significant 12 to $22 \%$ increase in protein content, an inconclusive reduction in fat content and an inconclusive increase in fibre after 6 hours of soaking and 24 hours of germination. Cereals and pseudo-cereals are considered a good source of protein. Our results are consistent with the results of Lemens et al. (2019). As we evaluated the changes in the total protein content, we concluded that the germination and subsequent drying of the seeds of the investigated cereals and pseudo-cereals did not significantly change the protein content compared to the input values. The finding that the protein in the final products can be described as a good source of protein makes an important result. This claim may be used to refer to a food product that contains at least $12 \%$ protein of the total energy value of the parent product (Commission Regulation (EU) No 432/2012). The germinated buckwheat flakes contain $14.4 \%$ of protein, the germinated gluten-free oat flakes $16.6 \%$ and germinated quinoa flakes $12.3 \%$ of the total energy value of the products.

Antioxidant activity (DPPH) decreased in the germinated quinoa flakes by $28.4 \%$, in the germinated buckwheat groats by $39.0 \%(\mathrm{p}=0.0044)$, in the germinated buckwheat flakes by $3.5 \%$, and in the germinated gluten-free oat flakes increased by $1100.9 \%$ $(\mathrm{p}=0.0011$ ). Antioxidant activity (FRAP) decreased in the germinated quinoa flakes by $0.4 \%$, in the germinated buckwheat groats by $20.6 \%(\mathrm{p}=0.0270)$, but it increased by $1.7 \%$ in the germinated buckwheat flakes 
and increased by $193.0 \%$ in the germinated gluten-free oat flakes ( $p=0.0005)$. Lemens et al. (2019) mention that germination in cereals increases antioxidant activity. Studies have shown its 1.2 to 2.9 -fold increase in various cereals, including oats. Higher antioxidant activity in germinated cereals is mainly due to the content of vitamin $\mathrm{E}$ and polyphenols, in which an increase due to the germination of different types of cereals has been demonstrated. The results of our research have shown a significant increase in the antioxidant activity of oats. However, the opposite trend was observed for pseudo-cereals, with a significant reduction in the antioxidant capacity of buckwheat (Lemens et al., 2019). Botero et al. (2012) monitored antioxidant activity (DPPH) during the 6 th to 10 th day of germination of cereals and pseudo-cereals. The lowest values were found on day 6 of germination, while the highest values were found in one sample on the eighth day of germination. No significant differences in antioxidant activity were found between germination days 7 and 10 .

The panel of trained tasters rated the germinated quinoa flakes (1.5) and germinated gluten-free oat flakes (1.6) as the best. The panel of lay evaluators rated the germinated buckwheat flakes (2.1) and germinated quinoa flakes (2.2) as the best. Germinated buckwheat groats were rated the worst by both panels (the trained tasters rated at 2.8, the untrained tasters at 3.4). All the germinated final products were evaluated as brittle and crisp (Table 4). The fragility and crispness of the evaluated products is given by their subsequent drying. Drying is a natural method of preservation in which water is removed and germinated seeds become very crisp (Bretherton, 2018; Galchus, 2014). Sensory-tested commodities are suitable for gluten-free diets, as they do not contain gluten or, in the case of gluten-free oats, comply with the Commission Implementing Regulation (EU) No $828 / 2014$ and thus offer opportunities to expand the range of cereals, germinated cereals and pseudo-cereals for gluten-free diet.

Seed germination tests were performed to verify the use of the input raw material for the manufacturing of germinated products. The germination results of seeds averaged at $89.7 \%$, naked oats without gluten at $32.7 \%$, and buckwheat at $66 \%$.

Microbiological analyses were performed to evaluate the entire manufacturing process, especially to control microbial contamination during the entire production. The determination of microorganisms and fungi indicators was performed. The results showed that the microbial contamination of the final products is at a low level and meets the requirements of ČSN 56 9609 (2008).

Table 2 Analysis of nutritional parameters and antioxidant activity of germinated quinoa flakes sand germinated gluten-free oat flakes

\begin{tabular}{|c|c|c|c|c|c|c|c|c|c|c|c|c|}
\hline \multirow[b]{2}{*}{$\begin{array}{c}\mathrm{N}=3 \text { samples input, } \\
3 \text { samples output }\end{array}$} & \multicolumn{6}{|c|}{ Germinated quinoa flakes } & \multicolumn{6}{|c|}{ Germinated gluten-free oat flakes } \\
\hline & $\begin{array}{c}\text { input } \\
\text { (Mean } \pm \text { SD) }\end{array}$ & $\begin{array}{l}{ }^{*} v \\
(\%)\end{array}$ & $\begin{array}{c}\text { output } \\
\text { (Mean } \pm \text { SD) }\end{array}$ & $\begin{array}{l}{ }^{*} \mathrm{v} \\
(\%)\end{array}$ & $\begin{array}{c}\text { change } \\
(\%)\end{array}$ & $p<0.05$ & $\begin{array}{c}\text { input } \\
\text { (Mean } \pm \text { SD) }\end{array}$ & $\begin{array}{l}* v \\
(\%)\end{array}$ & $\begin{array}{c}\text { output } \\
\text { (Mean } \pm \text { SD) }\end{array}$ & $\begin{array}{l}{ }^{*} \mathrm{v} \\
(\%)\end{array}$ & $\begin{array}{l}\text { change } \\
\text { (\%) }\end{array}$ & $\mathrm{p}<0.05$ \\
\hline Energy value $\mathrm{kJ} / 100 \mathrm{~g}$ & $1527.3 \pm 2.9$ & 0.2 & $1624.7 \pm 37.1$ & 2.3 & +6.4 & 0.0395 & $1532.7 \pm 40.7$ & 2.7 & $1674.3 \pm 33.3$ & 2.0 & +9.2 & 0.0015 \\
\hline Fat $\mathrm{g} / 100 \mathrm{~g}$ & $6.6 \pm 0.2$ & 2.9 & $6.4 \pm 0.4$ & 6.4 & -2.9 & 0.5042 & $6.5 \pm 0.1$ & 1.2 & $6.6 \pm 0.3$ & 4.1 & +1.2 & 0.6124 \\
\hline $\begin{array}{l}\text { of which saturated } \\
{ }^{*} \mathrm{FA} \mathrm{g} / 100 \mathrm{~g}\end{array}$ & $0.6 \pm 0.0$ & 1.6 & $0.6 \pm 0.1$ & 10.2 & +3.2 & 0.6220 & $1.2 \pm 0.1$ & 9.8 & $1.1 \pm 0.1$ & 7.6 & -11.3 & 0.1047 \\
\hline $\begin{array}{l}\text { Carbohydrates } \\
\mathrm{g} / 100 \mathrm{~g}\end{array}$ & $58.6 \pm 1.3$ & 2.2 & $63.9 \pm 3.6$ & 5.6 & +9.0 & 0.0574 & $54.8 \pm 4.4$ & 8.1 & $65.2 \pm 2.2$ & 3.3 & +18.9 & 0.0314 \\
\hline $\begin{array}{l}\text { of which } \\
\text { sugars } \mathrm{g} / 100 \mathrm{~g}\end{array}$ & $2.3 \pm 0.1$ & 2.5 & $2.3 \pm 0.8$ & 35.7 & 0 & 1.0000 & $1.3 \pm 0.1$ & 4.6 & $1.6 \pm 0.5$ & 31.4 & +28.9 & 0.3342 \\
\hline Proteins $\mathrm{g} / 100 \mathrm{~g}$ & $11.8 \pm 0.3$ & 2.3 & $11.8 \pm 0.6$ & 4.7 & -0.5 & 0.8447 & $15.9 \pm 0.2$ & 1.5 & $15.6 \pm 1.8$ & 11.6 & -1.5 & 0.8247 \\
\hline $\begin{array}{l}\text { Antioxidant activity } \\
\text { (DPPH) \%/100 g }\end{array}$ & $7.6 \pm 0.5$ & 7.1 & $5.4 \pm 0.9$ & 15.6 & -28.4 & 0.1010 & $0.4 \pm 0.1$ & 30.2 & $4.6 \pm 0.4$ & 7.5 & +1100.9 & 0.0011 \\
\hline $\begin{array}{l}\text { Antioxidant activity } \\
\text { (FRAP) \%/100 g }\end{array}$ & $4.6 \pm 0.1$ & 3.1 & $4.6 \pm 0.5$ & 11.8 & -0.4 & 0.9693 & $2.3 \pm 0.1$ & 2.8 & $6.7 \pm 0.2$ & 2.8 & +193.0 & 0.0005 \\
\hline$\beta$-Glucans \%/100 g & - & - & - & - & - & - & $4.0 \pm 0.1$ & 3.4 & $2.2 \pm 0.4$ & 17.6 & -43.7 & 0.0291 \\
\hline
\end{tabular}

${ }^{*}$ v/coefficient of variation; FA/fatty acids 
Table 3 Analysis of nutritional parameters and antioxidant activity of products from germinated buckwheat groats and flakes

\begin{tabular}{|c|c|c|c|c|c|c|c|c|c|c|c|c|}
\hline \multirow[b]{2}{*}{$\begin{array}{c}\mathrm{N}=3 \text { samples input, } \\
3 \text { samples output }\end{array}$} & \multicolumn{6}{|c|}{ Germinated quinoa flakes } & \multicolumn{6}{|c|}{ Germinated gluten-free oat flakes } \\
\hline & $\begin{array}{c}\text { input } \\
\text { (Mean } \pm S D)\end{array}$ & $\begin{array}{l}{ }^{*} \mathrm{v} \\
(\%)\end{array}$ & $\begin{array}{c}\text { output } \\
\text { (Mean } \pm \text { SD) }\end{array}$ & $\begin{array}{l}{ }^{*} \mathrm{v} \\
(\%)\end{array}$ & $\begin{array}{l}\text { change } \\
(\%)\end{array}$ & $p<0.05$ & $\begin{array}{c}\text { input } \\
(\text { Mean } \pm \text { SD) }\end{array}$ & $\begin{array}{l}* v \\
(\%)\end{array}$ & $\begin{array}{c}\text { output } \\
\text { (Mean } \pm \text { SD) }\end{array}$ & $\begin{array}{l}{ }^{*} v \\
(\%)\end{array}$ & $\begin{array}{l}\text { change } \\
(\%)\end{array}$ & $p<0.05$ \\
\hline $\begin{array}{l}\text { Energy value } \mathrm{kJ} / 100 \\
\mathrm{~g}\end{array}$ & $1509.3 \pm 2.1$ & 0.1 & $\begin{array}{c}1618.7 \pm \\
44.1 \\
\end{array}$ & 2.7 & +7.2 & 0.0458 & $1509.3 \pm 2.1$ & 0.1 & $1625.3 \pm 2.3$ & 0.1 & +7.7 & 0.0002 \\
\hline Fat $\mathrm{g} / 100 \mathrm{~g}$ & $3.1 \pm 0.2$ & 7.2 & $3.5 \pm 0.6$ & 16.1 & +12.9 & 0.2916 & $3.1 \pm 0.2$ & 7.2 & $3.3 \pm 0.1$ & 2.1 & +6.0 & 0.2345 \\
\hline $\begin{array}{l}\text { of which saturated } \\
{ }^{*} \mathrm{FA} g / 100 \mathrm{~g}\end{array}$ & $0.6 \pm 0.0$ & 6.6 & $0.7 \pm 0.2$ & 26.7 & +17.4 & 0.7952 & $0.6 \pm 0.0$ & 6.6 & $0.7 \pm 0.0$ & 3.7 & +23.8 & 0.0179 \\
\hline $\begin{array}{l}\text { Carbohydrates } \\
\mathrm{g} / 100 \mathrm{~g}\end{array}$ & $68.2 \pm 1.2$ & 1.7 & $71.5 \pm 2.5$ & 3.5 & +4.7 & 0.0548 & $68.2 \pm 1.2$ & 1.7 & $72.5 \pm 0.2$ & 0.3 & +6.3 & 0,0154 \\
\hline $\begin{array}{l}\text { of which sugars } \\
\mathrm{g} / 100 \mathrm{~g}\end{array}$ & $1.1 \pm 0.1$ & 5.4 & $0.6 \pm 0.1$ & 16.7 & -43.8 & 0.0339 & $1.1 \pm 0.1$ & 5.4 & $0.9 \pm 0.1$ & 6.2 & -12.5 & 0.0572 \\
\hline Fibre $\mathrm{g} / 100 \mathrm{~g}$ & $2.9 \pm 0.3$ & 11.2 & $3.9 \pm 1.4$ & 34.6 & +35.5 & 0.3686 & $2.9 \pm 0.3$ & 11.2 & $5,3 \pm 0.4$ & 6.8 & +85.1 & 0.0136 \\
\hline Proteins g/100 g & $12.5 \pm 0.5$ & 4.2 & $14.3 \pm 1.3$ & 9.1 & +14.8 & 0.0636 & $12.5 \pm 0.5$ & 4.2 & $13.4 \pm 0.1$ & 0.8 & +7.6 & 0.0586 \\
\hline $\begin{array}{l}\text { Antioxidant activity } \\
\text { (DPPH) \%/100 g }\end{array}$ & $19.3 \pm 0.1$ & 0.7 & $11.7 \pm 1.0$ & 8.4 & -39.0 & 0.0044 & $19.3 \pm 0.1$ & 0.7 & $18.6 \pm 0.5$ & 2,7 & -3.5 & 0.1380 \\
\hline $\begin{array}{l}\text { Antioxidant activity } \\
\text { (FRAP) } \% / 100 \mathrm{~g}\end{array}$ & $7.0 \pm 0.0$ & 0.2 & $5.5 \pm 0.4$ & 7.4 & -20.6 & 0.0270 & $7.0 \pm 0.0$ & 0.2 & $7.1 \pm 0.4$ & 6,0 & +1.7 & 0.6604 \\
\hline
\end{tabular}

${ }^{*} v /$ coefficient of variation; FA/fatty acids

Table 4 Sensory evaluations of germinated cereal and pseudo-cereal products

\begin{tabular}{|l|c|c|c|c|c|c|c|c|}
\hline \multirow{2}{*}{ Sensory } & \multicolumn{2}{|c|}{$\begin{array}{c}\text { Germinated } \\
\text { quinoa flakes }\end{array}$} & \multicolumn{2}{c|}{$\begin{array}{c}\text { Germinated } \\
\text { buckwheat groats }\end{array}$} & \multicolumn{2}{c|}{$\begin{array}{c}\text { Germinated } \\
\text { buckwheat flakes }\end{array}$} & \multicolumn{2}{c|}{$\begin{array}{c}\text { erminated gluten- } \\
\text { free oat flakes }\end{array}$} \\
\cline { 2 - 10 } & trained & untrained & trained & untrained & trained & untrained & trained & untrained \\
\hline Colour & 1 & 2 & 2 & 2 & 2 & 2 & 1 & 2 \\
\hline Appearance & 2 & 2 & 1 & 2 & 2 & 2 & 2 & 2 \\
\hline Aroma - pleasantness & 2 & 2 & 2 & 3 & 2 & 2 & 2 & 2 \\
\hline Fragrance- intensity & 1 & 2 & 2 & 4 & 2 & 2 & 2 & 2 \\
\hline Crispness & 1 & 1 & 1 & 2 & 1 & 1 & 2 & 2 \\
\hline Structure - size & 3 & 3 & 2 & 2 & 1 & 2 & 1 & 1 \\
\hline Taste- pleasantness & 2 & 2 & 3 & 3 & 1 & 2 & 2 & 3 \\
\hline Taste- intensity & 1 & 1 & 1 & 2 & 1 & 2 & 1 & 2 \\
\hline Salty taste & 1 & 1 & 1 & 1 & 1 & 1 & 1 & 1 \\
\hline Sweet taste & 2 & 1 & 2 & 1 & 2 & 1 & 2 & 1 \\
\hline Bitter taste & 1 & 1 & 1 & 1 & 1 & 1 & 1 & 1 \\
\hline Overall impression & 1.5 & 2.2 & 2.8 & 3.4 & 1.9 & 2.1 & 1.6 & 2.7 \\
\hline
\end{tabular}

\section{Conclusion}

Our results provided information on the nutritional composition and sensory evaluation of germinated products from quinoa, gluten-free oat and buckwheat. These germinated cereals and pseudo-cereals were processed by pressing and drying into groats and flakes. The products are low in fats, saturated fatty acids and sugars, and are a good source of protein and fibre. Germination and subsequent drying of quinoa, gluten-free oat and buckwheat seeds therefore did not reduce the quality of the nutritional properties and at the same time improved their digestibility. Germinated gluten-free oat flakes are also a good source of $\beta$-glucans, and our data have pointed out a significant increase in antioxidant activity of this product. The tasters evaluated all final products positively, especially for their fragility and taste. They can thus be used with advantage not only in conventional nutrition, but also in a gluten-free diet. 


\section{Acknowledgements}

This publication was created in cooperation with the Institute of Physiology and Pathophysiology, University of Ostrava, Faculty of Medicine, Research Institute of Brewing and Malting, PLC. Brno and SEMIX PLUSO spol. s r.o. Otice. Germinated seed products were developed by SEMIX PLUSO spol. s r.o. Otice within the frames of the subsidy title No. 17/005/16220/780/000054. Development of new products based on germinated pseudo-cereals, cereals and legumes. The results of sensory evaluation and nutritional analyses of monitored samples were used within the project SGS06/LF/2019-2020 Nutritional evaluation of cereals, pseudo-cereals, legumes and products from these foods and their use in gluten-free diet and supported by the Ministry of Agriculture of the Czech Republic, institutional support MZE-R01918.

\section{References}

Amistá, M., Tavano, 0. (2013). Influência da germinação e do processamento térmico na digestibilidade proteica e atividade de inibição de tripsina de grãos de quinoa. Brazilian Journal of Food Technology, 16(1), 52-58. https://doi.org/10.1590/S198167232013005000005

Benzie, I. F. F., Strain, J. J. (1999). Ferric reducing/antioxidant power assay: Direct measure of total antioxidant activity of biological fluids and modified version for simultaneous measurement of total antioxidant power and ascorbic acid concentration. Methods in Enzymology, 299, 15-27. https://doi.org/10.1016/s0076-6879(99)99005-5

Botero, O. M., Fong, C., Rothschild, J., Finney, P. (2012). Effects of germination on the nutritional profile of gluten-free cereals and pseudocereals: a review. Cereal Chemistry, 89(1), 1-14. https://doi. org/10.1094/CCHEM-01-11-0008

Bretherton, C. (2018). Naklíčeno!: semínka, obilniny a luštěniny. Praha: Euromedia. Esence. ISBN 978-80-7549-479-5.

Bulková, V. (2011). Rostlinné potraviny. Brno: Národní centrum ošetřovatelství a nelékařských zdravotnických oborů. ISBN 978-80-7013-532-7.

Commission Implementing Regulation (EU) No 828/2014 of 30 July 2014 on the requirements for the provision of information to consumers on the absence or reduced presence of gluten in food Text with EEA relevance. Available from: https://eur-lex.europa.eu/eli/ reg_impl/2014/828/oj

Commission Regulation (EU) No 432/2012 of 16 May 2012 establishing a list of permitted health claims made on foods, other than those referring to the reduction of disease risk and to children's development and health. Available from: https://eur-lex.europa.eu/legal-content/ EN/ALL/?uri=CELEX\%3A32012R0432

ČSN 569609 (2008). Guides to good hygiene and manufacturing practice - Microbiological criteria for foods. Principles for the establishment and aplication. Available from: http://www.fao.org/3/y1579e/ y1579e04.htm

EBC Analysis committee, 2010: Analytica-EBC. Nüremberg: Fachverlag Hans Carl, 794 p. ISBN 978-3-418-00759-5.

European Centre for Disease Prevention and Control and European Food Safety Authority. Shiga toxin/verotoxin-producing Escherichia coli in humans, food and animals in the EU/EEA, with special reference to the German outbreak strain STEC 0104 [online]. Stockholm, 2011 [cit. 2020-03-10]. ISBN 978-92-9193-298-6.

Galchus, R. (2014). Domácí klíčky: podrobný návod k domácímu nakličování po celý rok: luštěniny, obiloviny, výhonky, osení a další. Praha: Slovart. ISBN 978-80-7391-872-9.

Hoffmanová, I.; Sánchez, D. (2015). Non-celiac gluten sensitivity. Vnitrni Lekarstvi, [s. l.], v. 61, n. 3, p. 219-227.

ISO 16649-2 (2001). Microbiology of food and animal feeding stuffs Horizontal method for the enumeration of beta-glucuronidase-positive Escherichia coli - Part 2: Colony-count technique at 44 degrees C using 5-bromo-4-chloro-3-indolyl beta-D-glucuronide. Available from: https://www.iso.org/standard/29824.html

ISO 21527-2 (2008). Microbiology of food and animal feeding stuffs - Horizontal method for the enumeration of yeasts and moulds - Part 2: Colony count technique in products with water activity less than or equal to 0,95. Available from: https://www.iso.org/standard/38276.html

ISO 21528-2 (2017). Microbiology of the food chain - Horizontal method for the detection and enumeration of Enterobacteriaceae - Part 2: Colony-count technique Available from: https://www.iso.org/ standard/63504.html

Jimenez, M. D., Lobo, M., Sammán, N. (2019). „12th IFDC 2017 Special Issue - Influence of Germination of Quinoa (Chenopodium Quinoa) and Amaranth (Amaranthus) Grains on Nutritional and Techno-Functional Properties of Their Flours". Journal of Food Composition and Analysis, 84, 103290. https://doi.org/10.1016/j.jfca.2019.103290

Kocková, M., Dilongová, M., Hybenová, E., Valík, L. (2013). Evaluation of Cereals and Pseudocereals Suitability for the Development of New Probiotic Foods. Journal of Chemistry, Article, ID 414303, 8 pages. https://doi.org/10.1155/2013/414303

Lemmens, E., Moroni, A. V., Pagand, J., Heirbaut, P., Ritala, A., Karlen, Y., Lê, K.-A., Van, den Broeck, H.C., Brouns, F.J., De, Brier, N. and Delcour, J.A. (2019). Impact of Cereal Seed Sprouting on Its Nutritional and Technological Properties: A Critical Review. Comprehensive Reviews in Food Science and Food Safety, 18(1), 305-328. https://doi. org/10.1111/1541-4337.12414

Regulation (EC) No 1924/2006 of the European Parliament and of the Council of 20 December 2006 on nutrition and health claims made on foods. Available from: https://eur-lex.europa.eu/legal-content/ en/ALL/?uri=CELEX\%3A32006R1924

Regulation (EU) No 1169/2011 of the European Parliament and of the Council of 25 October 2011 on the provision of food information to consumers, amending Regulations (EC) No 1924/2006 and (EC) No $1925 / 2006$ of the European Parliament and of the Council, and repealing Commission Directive 87/250/EEC, Council Directive 90/496/ EEC, Commission Directive 1999/10/EC, Directive 2000/13/EC of the European Parliament and of the Council, Commission Directives 2002/67/EC and 2008/5/EC and Commission Regulation (EC) No 608/2004 Text with EEA relevance. Available from: https://eur-lex. europa.eu/legalcontent/EN/ALL/?uri=CELEX\%3A32011R1169

Rusydi, M. R., Azrina, A. (2012). Effect of germination on total phenolic, tannin and phytic acid contents in soy bean and peanut. International Food Research Journal 19(2), 673-677.

Saratu, A., Matthew, A. (2011). Nutritional composition of raw and processed pinto bean (Phaseolus vulgaris L.) grown in Nigeria. Journal of Food, Agriculture and Environment. 9(3-4), 72-80.

Schoenlechner, R. (2016). Properties of pseudocereals, selected speciality cereals and legumes for food processing with special attention to gluten-free products/Verarbeitungseigenschaften von Pseudogetreide, ausgewählten Spezialitätengetreide und Leguminosen mit speziellem Fokuss auf glutenfreie Produkte, Die Bodenkultur: Journal of Land Management, Food and Environment, 67(4), 239-248. https:// doi.org/10.1515/boku-2016-0019 
Sytar, O., Brestic, M., Zivcak, M., \& Tran, L. S. (2016). The Contribution of Buckwheat Genetic Resources to Health and Dietary Diversity. Current genomics, 17(3), 193-206. https://doi.org/10.2174/13892029 17666160202215425

Tian, B., Xie, B., Shi, J., Wu, J., Cai, Y., Xu, T., Xue, S., Deng, Q. (2010). Physicochemical changes of oat seeds during germination. Food Chemistry, 119(3), 1195-1200. https://doi.org/10.1016/j.foodchem.2009.08.035
Xu, L., Chen, L., Ali, B., Yang, N., Chen, Y., Wu, F., Jin, Z., \& Xu, X. (2017). Impact of germination on nutritional and physicochemical properties of adlay seed (Coixlachryma-jobi L.). Food chemistry, 229, 312-318. https://doi.org/10.1016/j.foodchem.2017.02.096

Zhang, G., Xu, Z., Gao, Y., Huang, X., Zou, Y. and Yang, T. (2015). Effects of Germination on the Nutritional Properties, Phenolic Profiles, and Antioxidant Activities of Buckwheat. Journal of Food Science, 80(5), H1111-H1119. https://doi.org/10.1111/1750-3841.12830 